\begin{tabular}{|c|c|}
\hline \multicolumn{2}{|c|}{ DYNAMIC ECONOMETRIC MODELS } \\
\hline DOI: http://dx.doi.org/10.12775/DEM.2018.002 & Vol. 18 (2018) 35-47 \\
\hline $\begin{array}{l}3,2018 \\
5,2018\end{array}$ & $\begin{array}{l}\text { ISSN (online) } 2450-7067 \\
\text { ISSN (print) } 1234-3862\end{array}$ \\
\hline
\end{tabular}

Kamal P. Upadhyaya, Raja Nag and Franklin G. Mixon Jr. *

\title{
Stock Market Prices and the Macroeconomics of Emerging Economies: the Case of India**
}

A b s tract. This paper investigates the relationship between stock prices and selected macroeconomic variables in India. The empirical results suggest that, in the long run, output growth and the exchange rate are positively related to stock prices, while money supply exhibits a negative relationship to stock market prices. In the short run most of the variation in the stock market is captured by its own innovation, although the exchange rate, the price level and the interest rate seem to have some effect on short-run stock prices.

$\mathrm{K}$ e y w o r d s: stock prices, Indian economy, emerging economies, Asian economics

J E L Classification: E00; E44

\section{Introduction}

Despite having the seventh largest economy in the world, India is also currently home to one of the world's fastest growing economies. This phenomenon is relatively recent. However, the Indian economy was more or less stagnant until the early 1980s. After enacting some major economic reforms

\footnotetext{
* Correspondence to: Kamal P. Upadhyaya, University of New Haven, Department of Economics, 300 Boston Post Road, West Haven, CT 06516, United States, e-mail: kupadhyaya@newhaven.edu; Raja Nag, New York Institute of Technology, Department of Accounting and Finance, Old Westbury Campus, Old Westbury, NY 11568, United States, e-mail: dnag@nyit.edu; Franklin G. Mixon, Jr., Columbus State University, Center for Economic Education, 4225 University Avenue, Columbus, GA 31907, United States, e-mail: mixon_franklin@columbusstate.edu.

${ }^{* *}$ The authors thank two anonymous referees for many helpful comments on a prior version. Any remaining errors are our own.

(C) 2018 Nicolaus Copernicus University. All rights reserved. http://www.dem.umk.pl/dem
} 
during the 1980s, the growth rate of India's economy accelerated, at an average 6.27 percent annual growth from 1980 to 2014. In 2014, India's economic growth rate stood at 7.24 percent, making that economy the fourteenth fastest growing economy in the world. In 2015, this growth rate increased to 7.36 percent, establishing India as the world's ninth fastest growing economy. In response to this level of GDP growth, stock prices in India have also been growing steadily. In 2003, total Indian stock market capitalization was $\$ 279$ billion dollars (slightly more than $40 \%$ of GDP), increasing to $\$ 1.516$ trillion (over $70 \%$ of GDP) in 2015. As a result, the growing Indian stock market has become an attractive investment opportunity not only for domestic investors but also for foreign investors.

There are several factors that contribute to, and influence, a company's stock price. It is in part determined by a firm's own company fundamentals, such as earning per share, dividend per share, book value and other internal factors that may affect the growth of the firm. In addition to its own internal factors, various external factors, such as domestic as well as foreign macroeconomic variables, also affect the firm's stock price ${ }^{1}$. According to Shleifer and Vishny (1997), successful corporate governance systems have significant legal protections for investors. Unfortunately, developing countries often lack such legal protection, which has led to concentrated ownership of equity and large investors. Thus, the findings from studies such as those cited above with regard to the relationship between macroeconomic variables and stock market prices cannot necessarily be generalized for an emerging economy such as India. As such, the objective of this study is to explore, identify and analyze the effects of various macroeconomic variables on equity prices in the Indian stock market, and to determine if these effects differ from those of developed countries such as the U.S., U.K. and Japan.

\section{Literature Review}

There is abundant theoretical literature that links the stock market with different macroeconomic variables (e.g., see Fama, 1981 and 1990; Chen, Roll and Ross, 1986). Empirical studies on the validity on this issue, however, began only few decades ago. One of the early studies on this topic is by Mukherjee and Naka (1995), which studied the relationship between macroeconomic variables such as the exchange rate, money supply, inflation, in-

\footnotetext{
${ }^{1}$ Given the strong link between the financial market and the macroeconomy, Andreou, Ghysels and Kourtellos (2013) use daily financial data to predict quarterly real economic activity.
}

Dynamic Econometric Models 18 (2018) 35-47 
dustrial production, long term government bond rates and call money rates and the Japanese stock market using a vector error correction model (VECM). Their findings suggest that there exists a long-run relationship between these macroeconomic variables and stock prices in Japan ${ }^{2}$.

Maysami and Koh (2000) developed a vector error correction model (VECM) to study the relationship between different macroeconomic variables and the stock market in Singapore. Their findings suggest that only price levels, money supply, short-term and long-term interest rates and exchange rates are cointegrated with Singapore's stock market. They also found that industrial production and trade, which essentially are the measures of real economic activity in Singapore, are not cointegrated with its stock market. Wongbangpo and Sharma (2002) also employ a VECM model to study the effects of different macroeconomic variables such as gross national product, the consumer price index, money supply, interest rate and the exchange rate on the stock prices in five ASEAN countries (Indonesia, Malaysia, Philippines, Singapore and Thailand). From the estimated model they observed both a short-term and long-term relationship between the various macroeconomic variables and stock prices. They also suggest that there exists a bi-directional causality between these macroeconomic variables and stock prices in every sample country in their study.

Abugri (2008) investigates the effect of macroeconomic volatility on stock returns in four Latin American countries (Argentina, Brazil, Chile and Mexico) using a vector autoregressive (VAR) model. The macroeconomic variables considered in the study include exchange rates, interest rates, industrial production and money supply. In addition to these macroeconomic variables they also included the MSCI world index and the U.S.three-month treasury yield. Based on their empirical findings they argue that the effect of macroeconomic variables on stock returns varies from country to country.

\footnotetext{
${ }^{2}$ Many researchers have studied the effects of macroeconomic variables on stock markets in different countries (e.g., see Fama, 1981; Chen, 1986; Geske and Roll, 1983; Huang and Kracaw, 1984; Kwon, Shin and Bacon, 1997; Humpe and Macmillan, 2008). Most of these studies are based on data from developed countries, such as the United States, United Kingdom, and Japan, where the financial sector is well developed. Corporate governance is at a mature state in these developed countries (Shleifer and Vishny, 1997). Although, according to Fama's efficient market hypothesis (EMH) continuum, the stock market in the U.S. is semi-strong efficient, it is still the most efficient capital market in the world. This is due largely to its well-evolved and mature corporate governance structure.
} 
Thus, it is not possible to determine, a priori, the effect of a change of any individual macroeconomic variable on market returns ${ }^{3}$.

Humpe and Macmillan (2009) examine, using Johansen's (1991) multivariate cointegration test, the importance of various macroeconomic variables in explaining long-term movements in the stock markets in both the U.S. and Japan. In doing so they include industrial production, the CPI, money supply, the long-term interest rate and stock prices in the statistical model.Their findings suggest that in the U.S., stock prices are positively related to industrial production and negatively related to both the CPI and long-term interest rates. The relationship between the stock returns and the U.S. money supply is found to be positive but insignificant. In case of Japan, stock prices are positively affected by industrial production but negatively affected by the money supply, while industrial production is negatively influenced by both the CPI and long-run interest rates. These authors conclude that the slump in the Japanese economy during the 1990s, and the subsequent liquidity trap experience there, may be responsible for these contrasting results.

Lastly, Al-Tamami and Rahman (2011) study the factors affecting stock prices in the United Arab Emirates (UAE). In doing so they develop a linear regression model in which stock prices are a function of earnings per share, dividend per share, oil prices, GDP, the CPI, interest rates and the money supply. Their analysis of time series data from 17 companies, divided into two groups - banks and non-banks - for the period 1995-2005 suggests that both GDP and the money supply positively affects both stock prices for banks and non-banks, whereas the CPI has a negative effect on both groups of stock prices. The interest rate fails to impact stock prices in either subgroup.

\section{Methodology and Data}

Based on the economics literature discussed above, the following model is developed,

$$
S P=\mathrm{f}(I I P, M S, W P I, R, E X C H),
$$

where the dependent variable, $S P$, represents India's stock price index. On the right-hand side are national output, IIP, as measured by the index of industrial production, the M1 money supply, MS, the price level, WPI, as

\footnotetext{
${ }^{3}$ An additional finding of interest in this study is that the global variables (i.e., the MSCI world index and the U.S. Treasury yield) are more consistent in explaining stock returns across the countries than are the domestic macroeconomic variables.
} 
measured by the wholesale price index, the nominal interest rate, $R$, as measured by the 10 -year Treasury rate, and the exchange rate, $E X C H^{4}$. An increase in economic activity not only increases corporate profitability, it may also increase expected future cash flows. This in turn will have a positive effect on stock prices. Accordingly, a decrease in economic activity may lower corporate profitability and expected future cash flows, which in turn negatively affects stock prices. Therefore, we expect a negative relationship between stock prices $(S P)$ and economic output $(I I P)$.

The relationship between the money supply and stock prices is not as straightforward. On one hand, an increase in the money supply, ceteris paribus, creates an excess supply of money balances and an excess demand for equity, resulting to an increase in equity prices (Dhakal, Kandil and Sharma, 1993; Wongbangpo and Sharma, 2002). On the other hand, an increase in the money supply may lead to inflation, which can lower corporate profits by increasing costs. Therefore, it is possible that an increase in the money supply will negatively affect stock prices. As such, the relationship between $M S$ and $S P$ is an empirical question. The expected relationship between $S P$ and WPI follows a similar path. In general, the price level is expected to have a negative effect on stock prices, given that inflation raises the costs of production, lowers profit and reduces future cash flows of a firm (Fama and Schwert, 1977; Fama, 1981; Chen et al., 1986; DeFina, 1991). Wongbangpo and Sharma (2002) argue, however, that inflation can have a positive effect on stock prices given because equities serve as a hedge against inflation given that they represent claims on real assets.

The relationship between the interest rate and the stock prices is expected to be negative. There are primarily two reasons for this expectation. First, an increase in the interest rate makes interest earning assets more attractive, leading investors to reallocate their portfolios by substituting equity for other assets. Second, an increase in the interest rate can reduce corporate profitability because of the concomitant increase in financing costs. In either case, stock prices $(S P)$ are negatively related to the interest rate $(R)$. Next, an increase in the exchange rate (i.e., currency depreciation) makes domestic goods (imported goods) relatively cheaper (more expensive) and, thus, more (less) competitive in the world (domestic) market. Under this circumstance, the volume of exports should increase and at the same time importcompeting domestic goods production also should increase. Under such

\footnotetext{
${ }^{4}$ Ideally GDP would have been more appropriate than the index of industrial production (IIP) as a measure of overall economic activity in India. However, a lack of monthly data for GDP resulted in our use of industrial production data as a measure of economic activity.
} 
a scenario, corporate profits, as well as future cash flows, should rise. The opposite is true in case of a decrease in the exchange rate (i.e., currency appreciation). Therefore, we expect a positive relationship between the exchange rate $(E X C H)$ and stock prices $(S P)$.

Monthly data from January 2006 to March 2016 are used to test the hypotheses developed above. For $S P$ (stock prices), the Bombay Stock Exchange Index (SENSEX) is used ${ }^{5}$. SENSEX is a free-float market-weighted stock market index of established companies which are listed in the Bombay Stock Exchange (BSE). It is the S\&P BSE Sensitive Index, which is widely considered as the benchmark index of domestic stock markets of India. The SENSEX has a free-float market capitalization of over $\$ 450$ billion (US). Data on IPP data are obtained from the Ministry of Statistics and Program Implementation of the Government of India., while data for the money supply $(M S)$, the price index $(W P I)$, the interest rate $(R)$ and the exchange rate $(E X C H)$ are obtained from various issues of International Financial Statistics, which is published by the International Monetary Fund. All of the data series, with the exception of the interest rate, are transformed into natural logs before the empirical estimation.

\section{Estimation and Empirical Findings}

Macroeconomic time series data are typically not stationary. The use of non-stationary data series produces spurious results. Therefore, it is important to test the stationarity of the each data series before estimating the model. To ensure the stationarity of the data series employed in this study, both an augmented Dickey-Fuller test (Said and Dickey, 1984) and PhillipsPerron test (Phillips and Perron, 1988; Perron, 1988) are conducted. Results from these tests are reported in Table 1. As indicated there, both the augmented Dickey-Fuller test and the Phillips-Perron test statistics do not reject the null hypothesis of "the existence of a unit root" in level form, while they do reject this null in the case of first differences for each of the series. These results suggest that all of the data series are integrated of order one, or are $\mathrm{I}(1)$.

After establishing the stationarity of the data series, Johansen's cointegration test (Johansen, 1988 and 1991; Johansen and Juselius, 1990) is conducted in order to test for long-run relationships among the variables. The AIC criterion is used to identify the optimal lag length. The Johansen's

\footnotetext{
5 The data for this variable is collected from CNBC money control: (http://www.moneycontrol.com/stocks/hist_index_result.php?indian_indices=4).
} 
cointegration test results are reported in Table 2, and indicate that one may reject the null hypothesis of "no cointegration". The long-run relationship between stock price indices $(S P)$ and the macroeconomic variables are derived after normalizing the coefficient of $S P$ to one, which occurs as follows ${ }^{6}$ :

$$
\begin{aligned}
& S P=30.61 I I P^{* * *}-10.07 M S^{* * *}-9.40 W P I+0.53 R+12.77 E X C H^{* * *}
\end{aligned}
$$

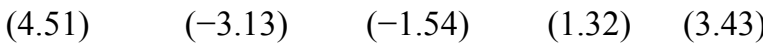

Table 1. Unit root test results

\begin{tabular}{ccccc}
\hline & \multicolumn{2}{c}{ Augmented Dickey-Fuller } & \multicolumn{2}{c}{ Phillips-Perron } \\
\cline { 2 - 5 } Variable & Level & FD & Level & FD \\
\hline logSP & -2.66 & $-10.07^{* * *}$ & -2.92 & $-10.06^{* * *}$ \\
loglIP & -2.54 & $-3.86^{* *}$ & -2.47 & $-21.55^{\star * *}$ \\
logMS & -2.05 & $-6.75^{\star * *}$ & -2.99 & $-13.89^{* * *}$ \\
$\log$ WPI & -2.47 & $-6.44^{* * *}$ & -1.76 & $-6.39^{* * *}$ \\
R & -2.99 & $-6.31^{* * *}$ & $-3.32^{* *}$ & $-11.92^{* * *}$ \\
$\log \mathrm{EXCH}$ & -2.59 & $-7.92^{* * *}$ & -2.20 & $-7.84^{* * *}$ \\
\hline
\end{tabular}

Notes: FD = first-difference. $* * *(* *)$ denotes significance at the $1 \%(5 \%)$ critical level.

As indicated in (2) above, the coefficient of IIP, which is a proxy for overall economic activity, is both positive and statistically significant. This finding is consistent with the notion that an increase (decrease) in economic activity increases (decreases) corporate profits and expected future cash flows, which in turn increases (decreases) stock prices.

Table 2. Johansen's cointegration test results

\begin{tabular}{cccc}
\hline $\mathrm{H}_{0}$ & Eigen Value & Trace Statistic & $5 \%$ Critical Value \\
\hline$r=0$ & 0.314 & $123.50^{\star * *}$ & 95.75 \\
$r \leq 1$ & 0.224 & $80.22^{\star * *}$ & 69.82 \\
$r \leq 2$ & 0.205 & $50.97^{\star *}$ & 47.85 \\
$r \leq 3$ & 0.129 & 24.53 & 29.79 \\
$r \leq 4$ & 0.058 & 8.64 & 15.49 \\
$r \leq 5$ & 0.015 & 1.73 & 3.84 \\
\hline
\end{tabular}

Note: $* * *(* *)$ signifies rejection of hypothesis at $1 \%(5 \%)$ critical level.

As discussed in the previous section of this study, the relationship between the money supply and stock prices is not straightforward, given that on the one hand an increase in money supply may increase stock prices by creating an excess supply of money balances, while on the other hand an increase in the money supply may lower stock prices by increasing the price level. In case of India, it appears as though an increase in the money supply

\footnotetext{
${ }^{6}$ The figures in the parentheses are $t$-values for the corresponding coefficients, where $* * *$ indicates significance at the $1 \%$ critical level.
} 
has a negative effect on stock prices in the long run, presumably because of its effect on the price level. This finding is consistent with Wongbangpo and Sharma's (2002) findings for Indonesia and the Philippines.

The coefficient on the price level (WPI) is negative, which suggests that an increase in the price level raises the production costs, lowers corporate profits and reduces expected future cash flows. The coefficient, however, is not statistically significant at the conventional level. Likewise, the coefficient attached to the interest rate $(R)$, which carries an unexpected sign, is not statistically significant. Wongbangpo and Sharma (2002) similarly found a positive long-run effect of long-term interest rates on stock prices for both Indonesia and the Philippines. Lastly, the coefficient of $E X C H$, which shows the long-run effect of the exchange rate $(E X C H)$ on stock prices, is positive and statistically significant. This finding is consistent with that of Mukherjee and Naka (1995) in the case of Japan and Indonesia, as well as that for the Philippines and Malaysia in the study by Wongbangpo and Sharma (2002).

After establishing the long run relationships between the variables in (1) above, we proceed to identify the short run relationship of the various macroeconomic variables in (1) stock prices $(S P)$ in India. Although recent studies provide examples of the efficacy of various types of Granger causality (e.g., Piłatowska, M., Włodarczyk, A., Zawada, 2014; Syczewska, 2014; Geise, A. and Piłatowska, 2016), the relationships examined in this study are best understood through the Granger causality test derived from the VECM estimation $^{7}$. The VECM Granger causality test results are reported in Table 3. As reported there, when all the macroeconomic variables are taken together the Chi-square value for $S P$ is statistically significant. This indicates that national output $(I I P)$, the money supply $(M S)$, the price level $(W P I)$, the interest rate $(R)$ and the exchange rate $(E X C H)$ jointly Granger-cause stock prices $(S P)$. Accordingly, we can observe that, with exception to price level (WPI), each of the variables in the model is jointly Granger-caused by the other variables.

\footnotetext{
${ }^{7}$ Vector Error Correction (VECM) includes lags of the dependent variables, in addition to its own lags. Econometircs software used (E-views-7) to estimate this equation also generates the cointegration equation which is reported in (2). Our methodology here is consistent with other similar studies (Maysami and Koh, 2000; Wongbangpo and Sharma, 2002; Abugri, 2008). Next, to ensure that the VECM estimation does not suffer from serial correlation, and that it is stable and robust, we conducted a Portmantau test (Castle and Hendry, 2010) for autocorrelation (for up to 10 lags). Encouragingly, the test result does not reject the null hypothesis of no autocorrelation.
}

Dynamic Econometric Models 18 (2018) 35-47 
Table 3. VEC Granger causality/Block exogeneity Wald test results

\begin{tabular}{cccccccc}
\hline & \multicolumn{7}{c}{ Excluded Variables } \\
\cline { 2 - 8 } Dependent Variable & $\Delta S P$ & $\Delta I I P$ & $\Delta M S$ & $\Delta W P I$ & $\Delta R$ & $\Delta E X C H$ & All \\
\hline$\Delta S P$ & $\mathrm{n} / \mathrm{a}$ & 4.95 & 10.57 & 5.29 & 7.25 & $25.52^{* * *}$ & $58.55^{* * *}$ \\
$\Delta I I P$ & 0.57 & $\mathrm{n} / \mathrm{a}$ & 11.45 & $18.27^{* *}$ & 7.66 & 9.95 & $61.67^{* * *}$ \\
$\Delta M S$ & 3.55 & $17.71^{* * *}$ & $\mathrm{n} / \mathrm{a}$ & 9.48 & 6.61 & 5.64 & $59.65^{* * *}$ \\
$\Delta W P I$ & 2.61 & 4.43 & 7.54 & $\mathrm{n} / \mathrm{a}$ & 4.62 & 3.54 & 31.28 \\
$\Delta R$ & 2.92 & 7.14 & 11.74 & 11.34 & $\mathrm{n} / \mathrm{a}$ & 3.21 & $54.32^{* *}$ \\
$\Delta E X C H$ & $25.30^{* * *}$ & 7.97 & 6.61 & 6.78 & 2.60 & $\mathrm{n} / \mathrm{a}$ & $56.53^{* *}$ \\
\hline
\end{tabular}

Note: The numbers above are chi-square statistics, where $* * *(* *)$ signifies the $1 \%(5 \%)$ critical level.

The effect of innovation in any variable on stock prices $(S P)$ can be sensitive to the ordering of the variables. Most of the literature places stock prices first, which are followed by the output level (i.e., GDP), CPI, money supply and interest rate. Given that the exchange rate is "pegged" in most developing countries it is considered as exogenous and typically placed last (see Naka and Tufte, 1997). The same ordering is followed in this study, with exception to the money supply. The ordering in this case is $S P, I I P, M S$, $W P I, R$ and $E X C H$. Table 4 reports the variance decomposition, also referred to forecast error variance (FEV) decomposition. In addition to the forecast error variance (FEV) decomposition of stock prices due to a shock in the macroeconomic variables, Table 4 also includes the variance decomposition of other variables due to a shock in other macroeconomic variables, including stock prices.

Table 4. Variance decomposition

\begin{tabular}{ccccccc}
\hline & \multicolumn{5}{c}{ Forecast Error Variance of Stock Prices Explained by Innovations } \\
\cline { 2 - 7 } Steps Ahead & SP & IIP & MS & WPI & $R$ & EXCH \\
\hline 3 & 89.16 & 1.40 & 1.06 & 1.18 & 0.35 & 6.85 \\
6 & 91.35 & 1.33 & 0.75 & 0.63 & 1.17 & 4.77 \\
9 & 87.33 & 1.26 & 0.50 & 2.11 & 2.98 & 5.82 \\
12 & 85.02 & 1.15 & 1.20 & 3.56 & 3.28 & 5.78 \\
& \multicolumn{7}{c}{} \\
\cline { 2 - 7 } 3 & Forecast Error Variance of Stock Prices Explained by Innovations in SP \\
\cline { 2 - 7 } 6 & n/a & 1.72 & 1.05 & 0.03 & 6.25 & 24.36 \\
9 & n/a & 11.62 & 1.49 & 0.24 & 9.39 & 35.79 \\
12 & n/a & 21.40 & 2.70 & 1.09 & 15.81 & 40.12 \\
& n/a & 22.90 & 3.41 & 2.16 & 21.67 & 40.72 \\
\hline
\end{tabular}

From the FEV it appears that most of the variance in stock prices $(S P)$ in the short horizon is mainly attributable to its own shock (e.g., 89 percent in third period, 91 percent in sixth period, and 85 percent in twelfth period). Interestingly, innovations in macroeconomic variables such as the output level $(I I P)$ and money supply $(M S)$ do not seem to attribute much in the vari- 
ance of stock prices $(S P)$. For example, IIP attributes less than two percent and $M S$ attributes around one percent over the time period. The effects of the price level (WPI) and the interest rate $(R)$ on the variance of $S P$ are little more than three percent by the ninth and twelfth time period. The only macroeconomic variable that has a larger effect on the variance of $S P$ is the exchange rate $(E X C H)$. Innovation in this variable attributes five percent or more from period three to period twelve. The effect of innovations on stock prices $(S P)$ and other macroeconomic variables on the variance output level $(I I P)$ is also of interest. It appears that a one standard deviation shock in $S P$ contributes to 22.90, 21.67 and 40.72 percent, respectively, in $I I P$ (output), the interest rate $(R)$ and the exchange rate $(E X C H)$, respectively, by within a year (i.e., period 12). The magnitude of the effect of innovation in $S P$ is much smaller in terms of the money supply $(M S)$ and the price level (WPI) compared with other variables.

The impulse response functions, which are available from the authors upon request, show the response of stock prices $(S P)$ to a one standard deviation shock to all the macroeconomic variables, and vice versa. In terms of the effect of a shock on $S P$ on itself, the effect initially keeps on rising, it peaks by period 6 and thereafter starts declining, which is compatible with the variance decomposition result. In the case of $I I P$, an innovation on its effect on $S P$ peaks at period two and becomes negative by period 12. Likewise, money supply and price level innovations also have some positive effect in the beginning, but eventually a negative effect prevails. Interest rate and exchange rate shocks have negative effects from the beginning to period 12. Overall, the impulse response functions corroborate the variance decomposition analyses.

\section{Conclusions}

In the midst of a growing economy, the stock market in India is also expanding and maturing, thus providing an opportunity for both domestic and foreign investors. India's stock market, like others, is affected by a number of macroeconomic variables, and while there are several empirical studies investigating the relationship between stock prices and the macroeconomy, particularly for developed economies, such a study of India's emerging economy is currently missing from the economics literature. As such, this study is to investigate the relationship between stock market prices in India and selected macroeconomic variables, such as overall economic output, the money supply, the price level, the interest rate and the exchange rate. Using monthly data from January 2006 to June 2016, both 
short-run and long-run relationships are estimated using mix of approaches, including a vector error correction model (VECM), Johansen's cointegration test, Granger causality tests and variance decomposition.

The empirical findings suggest that, in the long run, stock market prices in India are positively related to output growth, while money supply growth seems to be negatively related to stock prices. The Granger causality test indicates that, as a group, all of the macroeconomic variable in the model Granger-cause stock prices in India. Likewise, the combination of stock prices and the other variables (as a group) Granger-causes each of the macroeconomic variables in model, with the exception of the price level. Lastly, variance decomposition and impulse response functions suggest that the stock market dynamically interacts with key macroeconomic variables. More specifically, although most of the variation in the stock market is captured by its own innovation, the exchange rate, the price level and the interest rate seem to have some effect on stock price variation as well.

\section{References}

Abugri, B. A. (2008), Empirical Relationship between Macroeconomic Volatility and Stock Returns: Evidence from Latin American Markets, International Review of Financial Analysis, 17, 396-410, DOI: https://doi.org/10.1016/j.irfa.2006.09.002.

Al-Tamimi, H. A., Alwan, A. A. and Rahman, A. A. (2011), Factors Affecting Stock Prices in the UAE Financial Markets, Journal of Transnational Management, 16, 3-19, DOI: https://doi.org/10.1080/15475778.2011.549441.

Andreou, E., Ghysels, E. and Kourtellos, A. (2013), Should Macroeconomic Forecasters useDaily Financial Data and How? Journal of Business and Economic Statistics, 31, 240-251, DOI: https://doi.org/10.1080/07350015.2013.767199.

Castle, J. L. and Hendry, D. F. (2010), A Low-Dimension Portmanteau Test for NonLinearity, Journal of Econometrics, 158, 231-245, DOI: https://doi.org/10.1016/j.jeconom.2010.01.006.

Chen, N. F. Roll, R. and Ross, S. A. (1986), Economic Forces and the Stock Market, Journal of Business, 59, 383-403, DOI: https://www.jstor.org/stable/2352710.

DeFina, R. H. (1991), Does Inflation Depress the Stock Market? Federal Reserve Bank of Philadelphia Business Review, 17, 3-12, DOI: https://www.phil.frb.org.

Dhakal, D., Kandil, M. and Sharma, S. C. (1993), Causality between the Money Supply and Share Prices: A VAR Investigation, Quarterly Journal of Business and Economics, 32, 52-74, DOI: https://www.jstor.org/stable/40473092.

Fama, E. F. (1981), Stock Returns, Real Activity, Inflation and Money, American Economic Review, 71, 545-565, DOI: https://www.jstor.org/stable/1806180.

Fama, E. F., and Schwert, G. W. (1977), Human Capital and Capital Market Equilibrium, Journal of Financial Economics, 4, 95-125, DOI: https://doi.org/10.1016/0304-405X(77)90038-1.

Fama, E. F. (1990), Stock Returns, Expected Returns, and Real Activity, Journal of Finance, 45, 1089-1108, DOI: https://www.jstor.org/stable/2328716. 
Geise, A. and Piłatowska, M. (2016), Asymmetries in the Relationship between Economic Activity and Oil Prices in the Selected EU Countries, Dynamic Econometric Models 16, 65-86, DOI: http://dx.doi.org/10.12775/DEM.2016.004.

Geske, R. and Roll, R. (1983), The Fiscal and Monetary Linkage between Stock Returns and Inflation, Journal of Finance, 38, 1-33,

DOI: https://doi.org/10.1111/j.1540-6261.1983.tb03623.x.

Huang, R. D. and Kracaw, W. A. (1984), Stock Market Returns and Real Activity: A Note, Journal of Finance, 39, 267-273, DOI: https://www.jstor.org/stable/2327683.

Humpe, A. and Macmillan, P. (2009), Can Macroeconomic Variables Explain Long-Term Stock Market Movements? A Comparison of the US and Japan, Applied Financial Economics, 19, 111-119, DOI: https://doi.org/10.1080/09603100701748956.

Johansen, S. (1988), Statistical Analysis of Cointegration Vectors, Journal of Economic Dynamics and Control, 12, 231-254, DOI: https://doi.org/10.1016/0165-1889(88)90041-3.

Johansen, S. (1991), Estimation and Hypothesis Testing of Cointegration Vectors in Gaussian Vector Autoregressive Models, Econometrica, 59,1551-1580, DOI: https://www.jstor.org/stable/2938278.

Johansen, S. and Juselius, K. (1990), Maximum Likelihood Estimation and Inference on Cointegration - with Applications to the Demand for Money, Oxford Bulletin of Economics and Statistics, 52, 169-210, DOI: https://doi.org/10.1111/j.1468-0084.1990.mp52002003.x.

Kwon, C. S., Shin, T. S. and Bacon, F. W. (1997), The Effect of Macroeconomic Variables on Stock Market Returns in Developing Markets, Multinational Business Review, 5, 63-73, DOI: https://www.questia.com/library/journal/1P3-16999247.

Maysami, R. C. and Koh, T. S. (2000), A Vector Error Correction Model for the Singapore Stock Market, International Review of Economics and Finance, 9, 79-96, DOI: https://doi.org/10.1016/S1059-0560(99)00042-8.

Mukherjee, T. K. and Naka, A. (1995), Dynamic Relations between Macroeconomic Variables and the Japanese Stock Market: An Application of a Vector error Correction Model, Journal of Financial Research, 18, 223-237, DOI: https://doi.org/10.1111/j.1475-6803.1995.tb00563.x.

Naka, A. and Tufte, D. (1997), Examining Impulse Response Functions in Cointegrated Systems, Applied Economics, 29, 1593-1603, DOI: https://doi.org/10.1080/00036849700000035.

Perron, P. (1988), Trends and Random Walks in Macroeconomic Time Series: Further Evidence from a New Approach, Journal of Economic Dynamics and Control, 12, 297-332, DOI: https://doi.org/10.1016/0165-1889(88)90043-7.

Phillips, P. C. B. and Perron, P. (1988), Testing for a Unit Root in Time Series Regression, Biometrika, 75, 335-346, DOI: https://www.jstor.org/stable/2336182.

Piłatowska, M., Włodarczyk, A., Zawada, M. (2014), The Environmental Kuznets Curve in Poland - Evidence from Threshold Cointegration Analysis, Dynamic Econometric Models, 14, 51-70, DOI: http://dx.doi.org/10.12775/DEM.2014.003.

Said E., and Dickey, D. A. (1984), Testing for Unit Roots in Autoregressive-Moving Average Models of Unknown Order, Biometrika, 71, 599-607, DOI: https://www.jstor.org/stable/2336570.

Shleifer, A. and Vishny, R. W. (1997), A Survey of Corporate Governance, Journal of Finance, 52, 737-783, DOI: https://doi.org/10.1111/j.1540-6261.1997.tb04820.x.

Dynamic Econometric Models 18 (2018) 35-47 
Syczewska, E. M. (2014), The EURPLN, DAX and WIG20: The Granger Causality Tests Before and During the Crisis, Dynamic Econometric Models, 14, 93-104, DOI: http://dx.doi.org/10.12775/DEM.2014.005.

Wongbangpo, P. and Sharma, S. C. (2002), Stock Market and Macroeconomic Fundamental Dynamic Interaction: ASEAN-5 Countries, Journal of Asian Economics, 13, 27-51, DOI: https://doi.org/10.1016/S1049-0078(01)00111-7. 